\title{
Hyperspectral innovation on instruments and technologies at the European Space Agency
}

H. Strese, P. Ribes-Pleguezuelo, A. Zuccaro Marchi, L. Maresi

H. Strese, P. Ribes-Pleguezuelo, A. Zuccaro Marchi, L. Maresi, "Hyperspectral innovation on instruments and technologies at the European Space Agency," Proc. SPIE 11852, International Conference on Space Optics - ICSO 2020, 1185269 (11 June 2021); doi: 10.1117/12.2600234

SPIE Event: International Conference on Space Optics - ICSO 2021, 2021, Online Only 


\section{International Conference on Space Optics-ICSO 2020}

Virtual Conference

30 March-2 April 2021

Edited by Bruno Cugny, Zoran Sodnik, and Nikos Karafolas
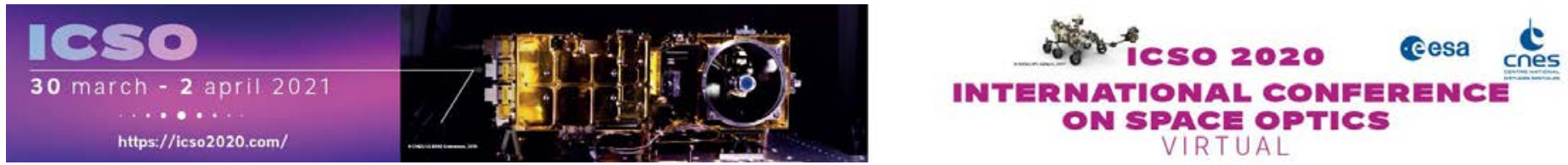

\section{Hyperspectral innovation on instruments and technologies at the European Space Agency}

\section{Cesa issopoceatings lecnes}




\title{
Hyperspectral innovation on instruments and technologies at the European Space Agency
}

\author{
H. Strese*a, P. Ribes-Pleguezuelo ${ }^{\text {a }}$, A. Zuccaro Marchi ${ }^{\mathrm{a}}$, L. Maresi ${ }^{\mathrm{a}}$ \\ ${ }^{a}$ ESA-ESTEC, Keplerlaan 1 - 2200 AG Noordwijk, The Netherlands
}

\begin{abstract}
Emerging spaceborne hyperspectral technologies answer a growing need to comprehend the Earth and its atmosphere. These technologies constitute a reliable source of information about Earth's environment. The near real-time distribution of Earth Observation (EO) information can be a requirement for certain applications, such as early warning and disaster management systems.

The last few decades have shown an increasing interest in hyperspectral observation data. This pushed the development of hyperspectral instrument technologies, also towards the miniaturization of instrument elements, taking advantage of electronics, new detector developments, material processes, hyperspectral filters, optical free-form design manufacturing and verification, on-board calibration techniques, on-board data processing and machine learning for image resolution enhancement. In parallel, the advent of smaller-size instruments, with lower development and operation costs is desirable to feed new data usage ideas and markets.

ESA actively participates in the development of hyperspectral instruments, each to satisfy specific performance needs. Its participation spans from the shaping of a vision for an instrument, to the initiation of projects and missions, through the support of development activities, on to the instrument launch and subsequent tasks.

The first hyperspectral instrument launched by ESA in 2001 was CHRIS, whose purpose was to improve knowledge on spectral reflectance from the Earth. Since then, the understanding of hyperspectral data and its significance has strongly risen and a sound heritage on hyperspectral instruments and applications exists by now. As for recent developments, a hyperspectral imaging mission study in the context of the Copernicus Expansion has been initiated and targets the realization of an instrument for routine observations in the visible-to-shortwave infrared range. In particular, it addresses the management of natural resources and enhances services for food security, sustainable agriculture and raw materials.

The degree of innovation, compactness, overall technical challenge and user needs can constitute the starting constraint for each development objective. The evolving technologies enable compactness and a better instrument performance to expand the scope of its use. In order to give a comprehensible overview of the current hyperspectral imagers and technologies, opportunities and challenges, this communication sheds light on different instrument characteristics and design concepts in a categorized view and provides the current status of key technologies.
\end{abstract}

Keywords: hyperspectral instruments, innovative technologies, spectroscopy, hyperspectral applications, ESA

\section{INTRODUCTION}

In the development of new hyperspectral technologies, the observation of our Earth and its atmosphere has become one of our focal points. Reliable information is needed to determine its state, analyze its utilization and finally draw conclusions from it concerning the environment's and our well-being.

*Helene.Strese@esa.int; phone +31 71565 5061; www.esa.int 
Recorded data is best made available shortly after its detection or in real-time. This is for example crucial for early warnings and reactions in disaster applications like floods and wild fire. The demand on information, retrieved from hyperspectral Earth observation, is rapidly increasing in the last 20 years and drives the advancement of related instrument technologies. Miniaturization, as well as higher spatial, temporal and spectral resolution are in pursuit of current technology studies and developments. This is enabled by progress in various relevant technology fields, as electronics miniaturization, new CMOS sensor developments, new materials and processes, hyperspectral filters, free-form optical design, free-form manufacturing and testing capabilities, on-board data processors and deep learning algorithms for image enhancement. Simultaneously, the reduction of cost for instruments and information provision is desired to feed and explore new data usage ideas and application markets.

In addition to the already launched or currently developed hyperspectral instruments in the frame of ESA missions, also smaller activities have an impact on the hyperspectral technology evolution. In the frame of the ESA General Support Technology Programme (GSTP), Basic Research Technology Programme (TRP) and Announcement of Opportunities (AO), several compact hyperspectral instruments already have been and are being developed. These R\&D activity programs support small development activities like CHIMA, where the realization of a new free-form grating based, high resolution instrument breadboard for hyperspectral atmosphere sensing applications was designed, built and tested, and also include instrument developments reaching flight-readiness maturity. One example is the compact, 6-unit CubeSat compatible HyperScout instrument, providing a wide swath for natural disaster monitoring applications, which was launched in 2018 for hardware and processing functionality testing.

\section{APPLICATIONS AND DESIGN DRIVERS}

Hyperspectral instruments in remote sensing have a wide range of applications, which is ever growing. For about 20 years, when the first hyperspectral remote sensing instruments started collecting data, the number of publications steadily increased. In Transon's survey on hyperspectral Earth observation applications ${ }^{1}$, a ranking for the application areas of most interest is given by the distribution of number of articles found with the Scopus platform. With 31\%, Natural Vegetation takes the first rank, then geology with $18 \%$, water resources with $15 \%$, agriculture with $14 \%$, land cover with $9 \%$, disaster with $5 \%$ and last, followed by the urban areas with $4 \%{ }^{1}$.

The growing interest in information obtained by hyperspectral data also opened new markets to data processing companies. Among the service areas that are enabled or enhanced by hyperspectral imaging is the displacement category, under which landslide, subsidence and infrastructure stability is covered. Further the marine service area, comprising sea water monitoring, algae bloom and fishing area. Examples for land services would be land cover, wildfire, illegal crops and soil sealing. And also urban change, infrastructure building and urban heat island are categories of urban dynamics and can be obtained as a service. Potential application areas could be listed almost indefinitely. The demand is obvious and the need for significant high-quality data from cost-effective instruments conflicts with high cost, large instrument applications. Technologies, data processing and applications stand here in close relation and are driven by each other. Each of them functions as a receiving and also as suggesting force in the current dynamic of hyperspectral data acquisition.

A clear trend goes towards cost-effective, miniaturized and high performant instruments. Miniaturization with steady performance does not happen without technology advancement, hence many upcoming technologies support exactly this path. A good number of technologies and instrument concepts have already been developed in the frame of ESA's R\&D activities.

However, high performance instruments enable applications out of reach for compact systems and may uncover uses that were not anticipated beforehand.

Spatial and temporal resolution, spectral resolution and signal-to-noise ratio are key parameters to perform trade-offs that determine cost and complexity of the instrument. In case of compact instruments, the trade-off is done by constraining the design in the mass, volume and power available on a picosatellite or a smallsat. Therefore, the development consisted in identifying technologies that make compact hyperspectrals achieving acceptable performance and innovative functionalities, such as on-board real-time processing. For what concerns large instruments, the development is geared to implement a technology step to match the challenging requirements of the Copernicus Space Component Expansion programme. 


\section{INSTRUMENT DEVELOPMENTS}

\subsection{Launched hyperspectral instruments}

ESA's history of bringing hyperspectral instruments into orbit starts in 2001, when CHRIS, an imaging spectrometer, on board of the PROBA-1 space platform, was launched to measure bidirectional reflectance distribution function data for a better understanding of spectral reflectance from Earth's vegetation. Since then, more instruments with hyperspectral capabilities have been launched for the observation of Earth's land and atmosphere. SCIAMACHY, two sounders for nadir and limb atmospheric observation have been launched on Envisat the year after. In 2004, OMI on board of Aura was also launched for monitoring of ozone and other trace gases. GOME-2 on a MetOp satellite (2006) and Tropomi on Sentinel5P (2017) have also been launched to observe the atmospheric chemistry with the detection of several non-continuous hyperspectral bands. With the ocean color, vegetation and aerosols in focus, the instrument OLCI was launched in 2016 on Sentinel-3, providing a partly continuous selection of hyperspectral bands. Finally, in 2019 the PRISMA instrument was launched on board of a mission with the same name, mainly focused on in-orbit technology demonstration, and for further monitoring of natural resources and the atmosphere. Some of these instruments were already achieving spectral resolutions of down to $0.22 \mathrm{~nm}$.

Table 1: Launched hyperspectral instruments ${ }^{2,3,4,5,6,7,8,9}$.

\begin{tabular}{|c|c|c|c|c|}
\hline Instrument & CHRIS & SCIAMACHY & OMI & GOME-2 \\
\hline Mission/Satellite & PROBA-1 & Envisat & Aura & MetOp \\
\hline Organization & Sira Technology Ltd & $\begin{array}{c}\text { Dornier } \\
\text { Satellitensysteme } \\
\text { GMBH, Fokker Space }\end{array}$ & $\begin{array}{l}\text { KNMI, NIVR, FMI, } \\
\text { TNO, VTT }\end{array}$ & Leonardo \\
\hline Purpose & $\begin{array}{l}\text { Land, vegetation, } \\
\text { ocean, atmosphere }\end{array}$ & $\begin{array}{c}\text { Limb / nadir for } \\
\text { atmospheric chemistry }\end{array}$ & $\begin{array}{l}\text { Monitor ozone and } \\
\text { other trace gases }\end{array}$ & $\begin{array}{l}\text { Atmospheric chemistry, } \\
\text { ozone, climate }\end{array}$ \\
\hline Launch date & 2001 & 2002 & 2004 & 2006 \\
\hline Altitude & $615 \mathrm{~km}$ & $774 \mathrm{~km}$ & $705 \mathrm{~km}$ & $827 \mathrm{~km}$ \\
\hline Swath & $14 \mathrm{~km}$ & 960km (nadir) & $2600 \mathrm{~km}$ & $\begin{array}{l}960 \mathrm{~km} \text { (main } \\
\text { channels) }\end{array}$ \\
\hline Design & Prism spectrometer & Grating spectrometer & Grating spectrometer & Grating spectrometer \\
\hline $\begin{array}{c}\text { Spectral } \\
\text { bands/range }\end{array}$ & $\begin{array}{c}410-1050 \mathrm{~nm} \\
18 / 63 \text { bands }\end{array}$ & $\begin{array}{c}214-2386 \mathrm{~nm} \\
8 \text { bands } \\
\text { (non-continuous) }\end{array}$ & $\begin{array}{c}270-500 \mathrm{~nm} \\
3 \text { bands }\end{array}$ & $\begin{array}{c}240-790 \mathrm{~nm} \\
4 \text { bands } \\
\text { (non-continuous) }\end{array}$ \\
\hline $\begin{array}{l}\text { Spectral } \\
\text { resolution }\end{array}$ & $1.3-12 \mathrm{~nm}$ & $0.22-1.48 \mathrm{~nm}$ & $0.5 \mathrm{~nm}$ & $0.24-0.53 \mathrm{~nm}$ \\
\hline Spatial resolution & $18 \mathrm{~m} / 36 \mathrm{~m}$ & $\begin{array}{c}3 \mathrm{~km} \text { vertical (limb) } \\
\text { 30/60 km (nadir } \\
\text { ALT/ACT) }\end{array}$ & $13 \mathrm{~km} / 24 \mathrm{~km}$ & 40 km (main channels) \\
\hline $\begin{array}{l}\text { Temporal } \\
\text { resolution }\end{array}$ & $\begin{array}{c}1 \text { week orbital repeat } \\
\text { cycle }\end{array}$ & 3 day global coverage & Daily global coverage & $\begin{array}{l}\text { 1.5-3 days global } \\
\text { coverage }\end{array}$ \\
\hline Weight & $14 \mathrm{~kg}$ & $198 \mathrm{~kg}$ & $65 \mathrm{Kg}$ & $73 \mathrm{~kg}$ \\
\hline Power & $8 \mathrm{~W}$ & $122 \mathrm{~W}$ & $66 \mathrm{~W}$ & $42 \mathrm{~W}$ \\
\hline Instrument & OLCI & & & PRIMSA \\
\hline
\end{tabular}




\begin{tabular}{|c|c|c|c|}
\hline Mission/Satellite & Sentinel-3 & Sentinel-5P & PRISMA \\
\hline Organization & TAS & Airbus, TNO, SRON, KNMI & Selex Galileo \\
\hline Purpose & $\begin{array}{c}\text { Ocean and land color, vegetation } \\
\text { aerosol, clouds }\end{array}$ & $\begin{array}{c}\text { Atmospheric chemistry, air } \\
\text { quality }\end{array}$ & $\begin{array}{c}\text { Technology demonstration, and } \\
\text { to monitor natural resources and } \\
\text { atmosphere }\end{array}$ \\
\hline Launch date & 2016 & 2017 & $614 \mathrm{~km}$ \\
\hline Altitude & $810 \mathrm{~km}$ & $824 \mathrm{~km}$ & $30 \mathrm{~km}$ \\
\hline Swath & $1270 \mathrm{~km}$ & $2600 \mathrm{~km}$ & $400-2500 \mathrm{~nm}$ \\
\hline Design & Grating spectrometer & Grating spectrometer & $12 \mathrm{~nm}$ \\
\hline $\begin{array}{c}\text { Spectral } \\
\text { bands/range }\end{array}$ & $400-1020 \mathrm{~nm}$ & $270-2385 \mathrm{~nm}$ & 3 bands \\
& 21 bands (partly continuous) & $($ non-continuous $)$ & $30 \mathrm{~m}$ \\
\hline $\begin{array}{c}\text { Spectral } \\
\text { resolution }\end{array}$ & $2.5-40 \mathrm{~nm}$ & $0.25-0.55 \mathrm{~nm}$ & TBC \\
\hline $\begin{array}{c}\text { Spatial resolution } \\
\text { Temporal } \\
\text { resolution }\end{array}$ & 2 days global coverage & Daily global coverage & $90 \mathrm{Kg}$ \\
\hline $\begin{array}{c}\text { Weight } \\
\text { Power }\end{array}$ & $150 \mathrm{~kg}$ & $220 \mathrm{~kg}$ & $110 \mathrm{~W}$ \\
\hline
\end{tabular}

Some the fore-mentioned hyperspectral devices, due to their success, had been used in following-up missions, as for example the GOME-2 sent initially in 2006 on board of the MetOp-A, but also later used with a similar design in the MetOp-B (2012) and the MetOp-C (2018) missions.

\subsection{Hyperspectral in development}

Some of the hyperspectral instruments in development are the UVN/Sentinel-4 and UVNS/Sentinel-5, dedicated to atmospheric chemistry. The former is designed to operate from geostationary orbit, while latter on sunsynchronous low Earth orbit. They are scheduled for launch for the coming few years. Further, the Floris instrument for vegetation fluorescence mapping will be launched in 2024 in the frame of the Fluorescence Explorer (FLEX) mission. Just recently, the phase B2 has been initiated for a Copernicus candidate mission for a potential Next-Generation Sentinel satellite. The goal of this provisioned instrument CHIME is to be useful for agriculture and the exploration of natural resources. This includes for example crop health assessment, species identification, soil property and mineral mapping. In order to provide this kind of information a spatial resolution of $20 \mathrm{~m}$ to $30 \mathrm{~m}$ and a spectral resolution of $10 \mathrm{~nm}$ is requested for a continuous spectrum recording from $400 \mathrm{~nm}$ to $2500 \mathrm{~nm}$. This, in combination with a very high signal-to-noise ratio performance and a rather short revisit time, states a considerable challenge for the instrument designer and will drive new technology developments. In addition to CHIME, other hyperspectral missions are proposed, such as the Copernicus candidate mission, named CO2M, with hyperspectral sensing capabilities for atmospheric CO2 detection, and TRUTHS, aiming at establishing an SI-traceable space-based climate and calibration observing system to improve confidence in climate-change forecasts (currently in Phase A).

Table 2: Hyperspectral instruments in development phase $\mathrm{e}^{10,11,12,13,14,15,16,17}$.

\begin{tabular}{|c|c|c|c|c|c|c|}
\hline Instrument & UVN & UVNS & Floris & CHIME & $\overline{\mathrm{CO}} \mathrm{M}$ & HIS \\
\hline $\begin{array}{l}\text { Mission } \\
\text { /Satellite }\end{array}$ & $\begin{array}{c}\text { Sentinel-4 on } \\
\text { MTG }\end{array}$ & $\begin{array}{c}\text { Sentinel-5 on } \\
\text { MetOp SG }\end{array}$ & $\begin{array}{l}\text { Earth explorer } \\
\text { missions / } \\
\text { FLEX }\end{array}$ & $\begin{array}{c}\text { CSC Expansion } \\
\text { study for NG } \\
\text { Sentinels }\end{array}$ & $\begin{array}{c}\text { CSC Expansion } \\
\text { study for NG } \\
\text { Sentinels }\end{array}$ & $\begin{array}{c}\text { Earth explorer / } \\
\text { TRUTHS }\end{array}$ \\
\hline
\end{tabular}




\begin{tabular}{|c|c|c|c|c|c|c|}
\hline Organization & Airbus & Airbus & Leonardo & $\begin{array}{l}\text { TAS, OHB, } \\
\text { Leonardo }\end{array}$ & TBC & Airbus \\
\hline Purpose & $\begin{array}{l}\text { Atmospheric } \\
\text { chemistry }\end{array}$ & $\begin{array}{l}\text { Atmospheric } \\
\text { chemistry }\end{array}$ & $\begin{array}{c}\text { Vegetation } \\
\text { fluorescence } \\
\text { mapping }\end{array}$ & $\begin{array}{c}\text { Agriculture, } \\
\text { raw materials, } \\
\text { environment }\end{array}$ & $\begin{array}{c}\text { Atmospheric } \\
\text { CO2 detection }\end{array}$ & $\begin{array}{c}\text { SI-traceable } \\
\text { space climate } \\
\text { and calibration } \\
\text { system }\end{array}$ \\
\hline Status & $\begin{array}{c}\text { Launch planned } \\
2023\end{array}$ & $\begin{array}{c}\text { Launch planned } \\
2022\end{array}$ & $\begin{array}{c}\text { Launch planned } \\
2022\end{array}$ & Phase B2 & Phase B2 & Phase A \\
\hline Altitude & $35786 \mathrm{~km}$ & $835 \mathrm{~km}$ & $800 \mathrm{~km}$ & $632 \mathrm{~km}$ & TBC & $600 \mathrm{~km}$ \\
\hline Swath & $8 \mathrm{~km}$ & $2715 \mathrm{~km}$ & $150 \mathrm{~km}$ & $128 \mathrm{~km}$ & $>200 \mathrm{~km}$ & $100 \mathrm{~km}$ \\
\hline Design & $\begin{array}{c}\text { Grating } \\
\text { spectrometer }\end{array}$ & $\begin{array}{c}\text { Grating } \\
\text { spectrometer }\end{array}$ & $\begin{array}{c}\text { Grating } \\
\text { spectrometer }\end{array}$ & TBC & TBC & TBC \\
\hline $\begin{array}{c}\text { Spectral } \\
\text { bands/range }\end{array}$ & $\begin{array}{c}305-775 \mathrm{~nm} \\
3 \text { hyperspectral } \\
\text { bands }\end{array}$ & $\begin{array}{c}270-2385 \mathrm{~nm} \\
7 \text { hyperspectral } \\
\text { bands }\end{array}$ & $\begin{array}{c}500-780 \mathrm{~nm} \\
9 \text { hyperspectral } \\
\text { bands }\end{array}$ & $400-2500 \mathrm{~nm}$ & $\begin{array}{c}747-2095 \mathrm{~nm} \\
3 \text { hyperspectral } \\
\text { bands }\end{array}$ & $320-2400 \mathrm{~nm}$ \\
\hline $\begin{array}{c}\text { Spectral } \\
\text { resolution }\end{array}$ & $0.12-0.5 \mathrm{~nm}$ & $0.25-1 \mathrm{~nm}$ & $0.1-2 \mathrm{~nm}$ & $10 \mathrm{~nm}$ & $0.1-0.55 \mathrm{~nm}$ & TBC \\
\hline $\begin{array}{c}\text { Spatial } \\
\text { resolution }\end{array}$ & $8 \mathrm{~km}$ & $7.5 \mathrm{~km}$ & $300 \mathrm{~m}$ & $20-30 \mathrm{~m}$ & $2 \mathrm{~km}$ & TBC \\
\hline $\begin{array}{l}\text { Temporal } \\
\text { resolution }\end{array}$ & $60 \mathrm{~min}$ & $\begin{array}{c}\text { Repeat cycle } 29 \\
\text { days }\end{array}$ & 30 days & 10-15 days & $\sim 3$ days & TBC \\
\hline Weight & $150 \mathrm{~kg}$ & $250 \mathrm{~kg}$ & TBC & $1640 \mathrm{~kg}$ & TBC & TBC \\
\hline Power & $180 \mathrm{~W}$ & $220 \mathrm{~W}$ & TBC & TBC & TBC & TBC \\
\hline
\end{tabular}

ESA also contributes to the development of novel innovative technologies in the field of optical design, manufacturing, materials, hyperspectral filters, CMOS detectors, electronics miniaturization and on-board data processing capabilities. These in turn enable a more compact design of such instruments and enable their accommodation on smaller platforms. Since several years these developments go towards miniaturization, cost-effectiveness and short revisit, while maintaining a high performance.

\subsection{HyperScout $1 \& 2$}

One of the instruments, developed in the frame of an ESA In-Orbit Demonstration GSTP activity, is the VNIR (400 nm to $1000 \mathrm{~nm}$ ) hyperspectral instrument HyperScout. It has a large field of view ( $31^{\circ}$ across track), a spectral resolution of about $15 \mathrm{~nm}$ and it takes advantage of a hyperspectral linear variable filter technology in combination with a CMOS detector. The wide field three-mirror anastigmat (TMA) telescope designing and manufacturing capabilities, in combination with an overall athermal design and the use of COTS-based miniaturized electronics contribute to its compact size and its ease of alignment. In addition, intelligent on-board processing shortens the time from data acquisition to the access of relevant information widening the scope of land and vegetation operational applications. In 2018 the HyperScout Proto-Flight Model was launched on a 6-unit Gomx-4B CubeSat in order to test the hardware and processing functionalities and is now operational with a swath of $220 \mathrm{~km}$ and a ground sampling distance of $70 \mathrm{~m}$ at $500 \mathrm{~km}$ altitude. Since any CubeSat platform has limited downlink capabilities, one of the main functionalities of this mission was to prove the L0-L2A on-board processing, to cope with the $1 \mathrm{~TB}$ hyperspectral data generation per orbit. Only application-specific high level processed hyperspectral cubes are therefore downloaded to ground. The company's future target is to achieve a higher revisit with a satellite constellation ${ }^{18,19}$.

HyperScout-1 has been proven operative well beyond its commissioning phase. Last image was taken in Spring 2020. In the recent years, cosine implemented the concept by adding a Thernal Infrared channel, and the device was updated also with enhanced Artificial Intelligence capabilities. The resulting Hyperscout-2 was launched in 2020 and is being successfully operating since ${ }^{20,21}$. 

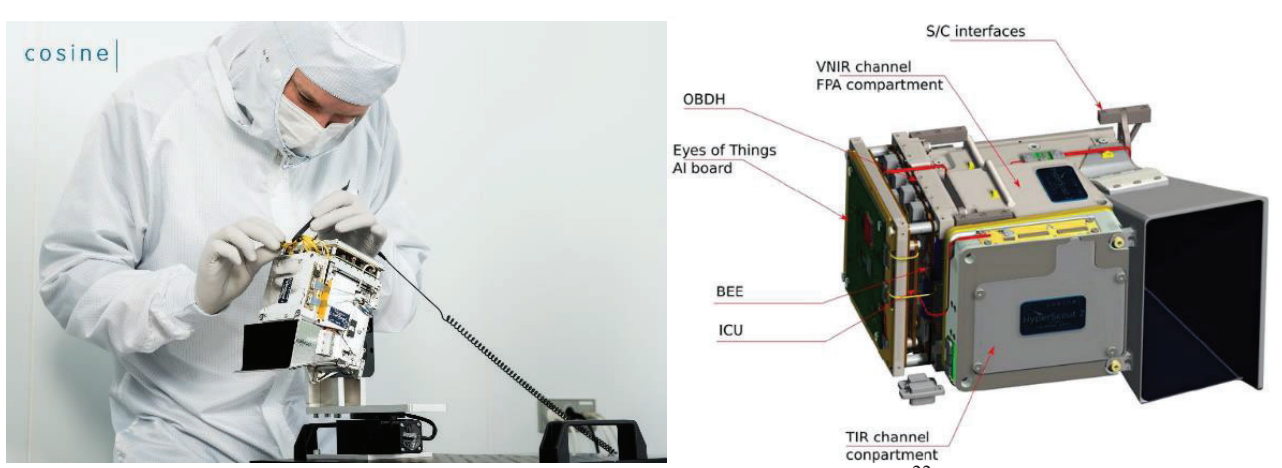

Figure 1: Left: HyperScout-2 flight model. Right: HyperScout-2 design [credit cosine] ${ }^{22}$.

\subsection{STREEGO \& HYPERSTREEGO}

Another instrument, developed during an ESA R\&D activity, is STREEGO. The main focus was to develop an innovative optical design with specifications that cover specific remote sensing product market needs. The result was a smallsat compatible multispectral imager with upgrade capabilities for hyperspectral performance. The optics consist of an unobscured three-mirror anastigmat, which can achieve hyperspectral performance in combination with integrated linear variable filters and newly developed sensors, such as a $12 \mathrm{Mpx}$ CMOS detector with $5.5 \mu \mathrm{m}$ pixel size. With this composition, up to 150 spectral bands over a spectral range of $430 \mathrm{~nm}$ to $880 \mathrm{~nm}$ can be provided. With a $200 \mathrm{~mm}$ aperture diameter and a field of view of $2^{\circ}$ (F-number 6), a spatial resolution of $5.5 \mathrm{~m}$ to $11 \mathrm{~m}$ can be achieved, depending on the number of selected spectral bands. Further, the design is athermal due to the utilization of CTE (coefficient of thermal expansion) matched materials for mirrors and structure, which simplifies the platform thermal control. The identified data products for STREEGO are related to agriculture, forestry, resources monitoring and urban development. Currently, the instrument is at Proto-Flight Model maturity level and a 2-satellite constellation could be thinkable in order to reduce the revisit time. Below (Figure 2), the STREEGO instrument is shown 22,23 .

A further development is the HyperSTREEGO concept, which uses the combination of the two already mentioned instruments, namely the HyperScout/Panorama (with a pointing ahead and image processing capabilities) and the STREEGO (with multi/hyperspectral capabilities).
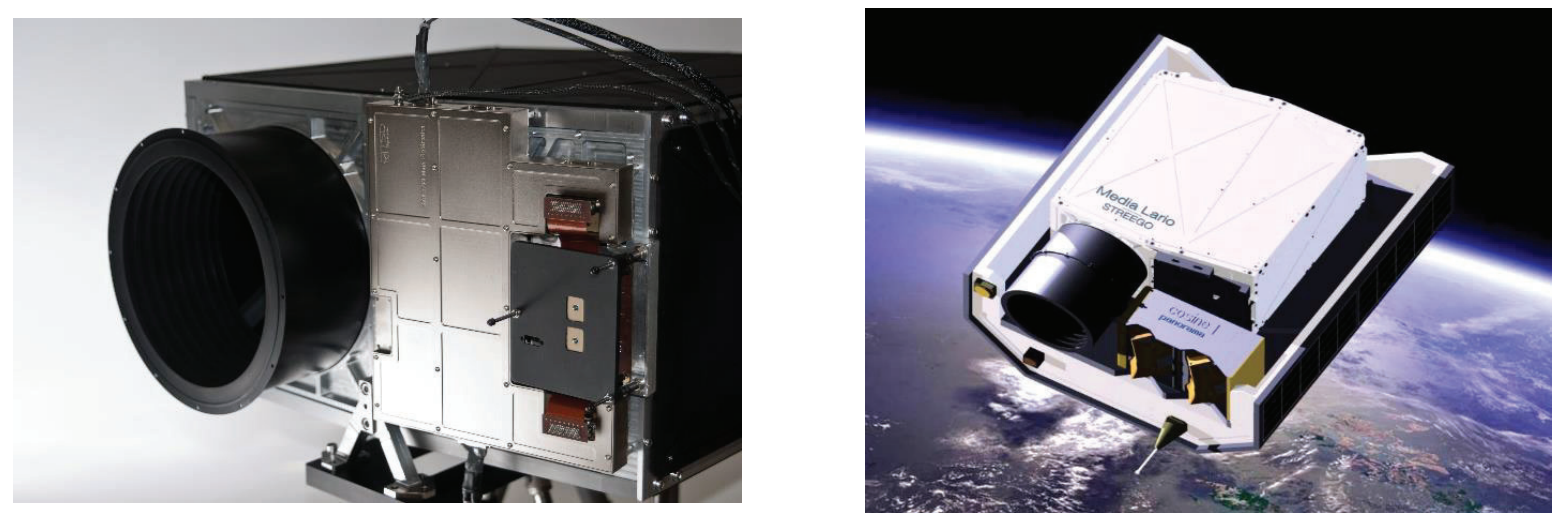

Figure 2: Left: packaged STREEGO instrument; Right: HyperSTREEGO artist's impression. In white, STREEGO main body; in purple, HyperScout/Panorama [credits Media Lario, cosine] ${ }^{24}$. 


\subsection{ELOIS}

ELOIS is a hyperspectral instrument at Engineering Model maturity, targeted for land observation, developed and tested within a General Support Technology Programme. This instrument covers the spectral range from $400 \mathrm{~nm}$ to $2450 \mathrm{~nm}$ and provides a spatial resolution of $35 \mathrm{~m}$ by incorporating three latest technology advances. First, a complex blazed free-form grating manufactured via single point diamond turning. Second, free-form optical design is applied; and third, hyperspectral back-side illuminated CMOS sensors are used, which enhances the instrument sensitivity. Another parameter, improving the instrument's sensitivity, is the low F-number of 2.1, which aids to maintain a high signal-tonoise ratio.

The summary of these technologies enables a smaller, cost-effective instrument with less components and less power consumption. Currently the development of the Qualification Model is ongoing. The non-exhaustive applications are in agriculture, forestry, environment and water monitoring, natural resources and disaster management and coastal monitoring ${ }^{19,25}$.

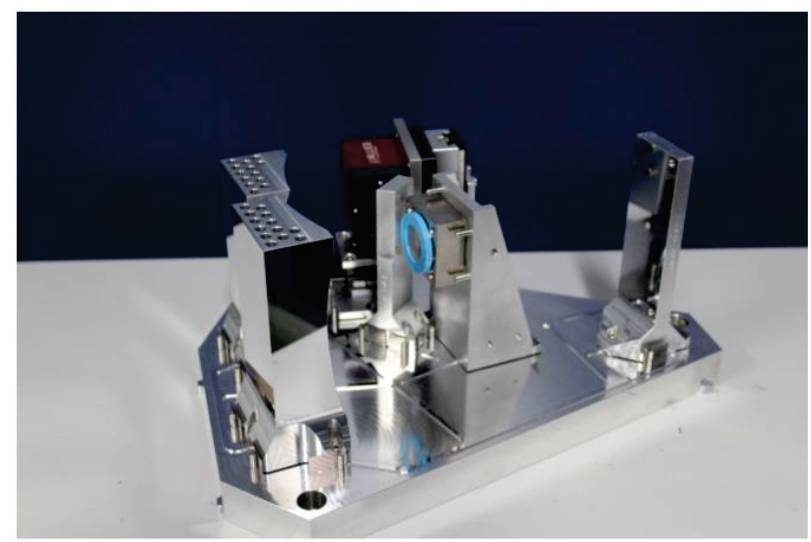

Figure 3: ELOIS spectrometer breadboard [credits AMOS].

\subsection{CHIMA}

With ELOIS as precedent activity, the ESA Basic Research Technology Programme CHIMA was initiated to modify the instrument design (Figure 4) for atmospheric chemistry observation purposes. Especially in atmospheric sensing, a high spectral resolution and a high signal-to-noise ratio is needed. Following, the feasibility of a modified Offner-spectrometer with a holographically replicated blazed convex free-form grating of $1000 \mathrm{lp} / \mathrm{mm}$, a curved slit and a keystone corrector were studied. The output was an athermal breadboard, covering the $600 \mathrm{~nm}$ to $800 \mathrm{~nm}$ spectral range with a spectral resolution of $0.5 \mathrm{~nm}$. During assembly and performance tests, an excellent optical quality, easy alignment and expected spatial and spectral performances were $\operatorname{proven}^{19}$.
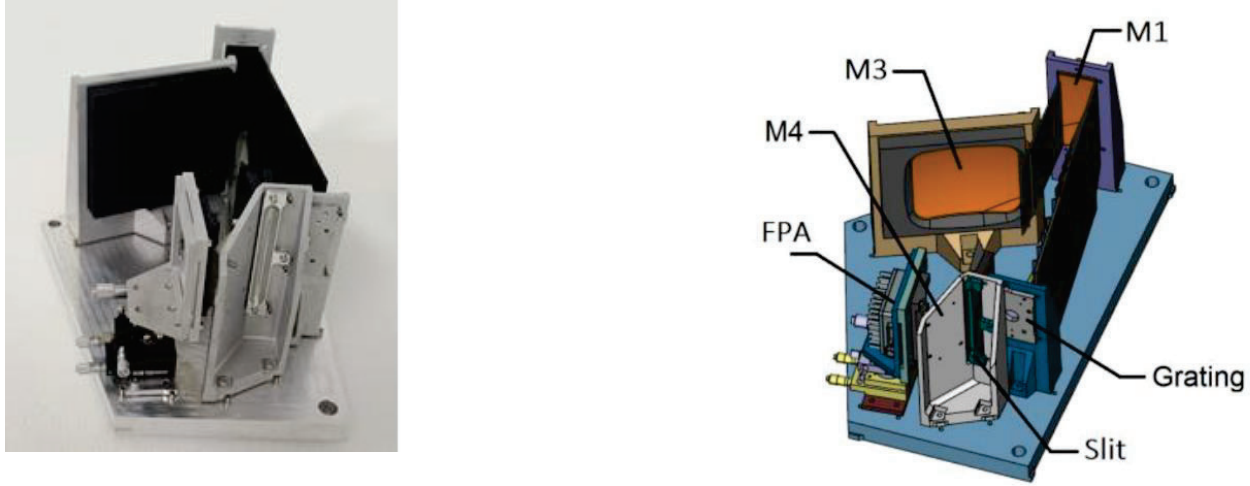

Figure 4: Left: CHIMA spectrometer breadboard; Right: CHIMA breadboard CAD drawing [credits AMOS, Horiba JobinYvon] 


\subsection{CSIMBA}

The Compact Smart spectral Imager for Monitoring Bio-agricultural Areas (CSIMBA) is an instrument suited for a 12-unit CubeSat In-Orbit Demonstration mission. The manufacturing of the Proto-Flight Model is currently in progress. CSIMBA is based on the development achieved with previous development activities based on the design that uses thin film interference filters directly deposited on a 12 Mpixel CMOS 2D detector array (Figure 5, right). The covered spectrum is from $475 \mathrm{~nm}$ to $900 \mathrm{~nm}$ and with a typical spectral resolution of $5 \mathrm{~nm}$. The instrument provides swath of $80 \mathrm{~km}$ and a spatial resolution of $20 \mathrm{~m}$ from $500 \mathrm{~km}$ satellite orbit. The technology of filters directly deposited on the CMOS detector enables geometric filter designs and pixel precise spectral response control. Each spectral band covers 12 pixels to increase the signal-to-noise ratio. The detector read-out electronics provide a very high frame rate for image acquisition. The system will be provided with on-board data processing for real time compression. Further possibilities of image processing are planned. The long-term goal is to build up a constellation of hyperspectral nanosats, capable of enhanced vegetation monitoring of agricultural fields and the biodiversity status with an hourly revisit rate ${ }^{19,26}$.
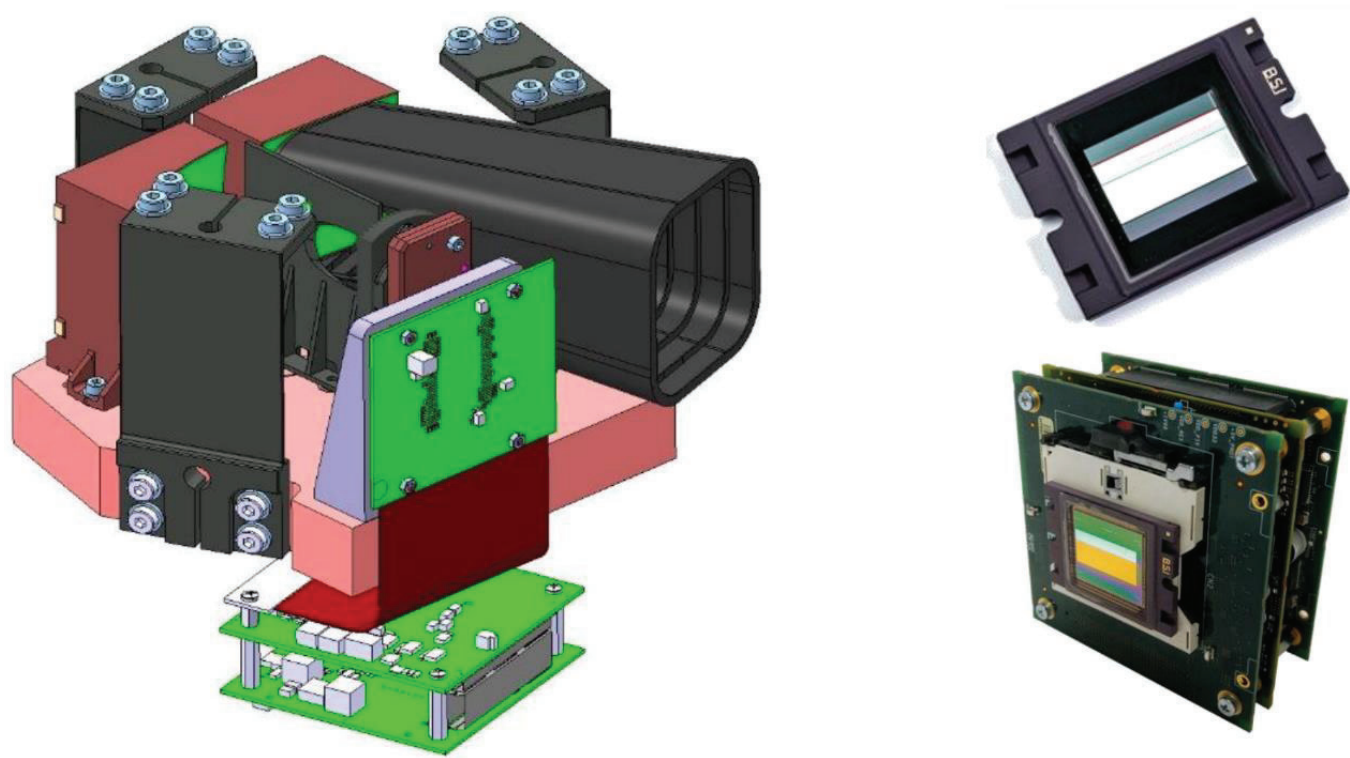

Figure 5: Left: CSIMBA TMA; Right: Hyperspectral chip (+LVF) [credits VITO, AMOS, imec]

All mentioned technology studies and built systems in the frame of a General Support Technology Programme or Basic Research Technology Programme activity are listed below with a selected subset of characteristics.

Table 3: Hyperspectral instrument and technology developments under General Support Technology Programme or Basic Research Technology Programme study $20,21,22,23,24,25,26$.

\begin{tabular}{|c|c|c|c|c|c|c|}
\hline Instrument & ELOIS & HyperScout-1 & CHIMA & STREEGO & HyperScout-2 & CSIMBA \\
\hline Platform & $\begin{array}{c}\text { Micro-or } \\
\text { minisatellite }\end{array}$ & $\begin{array}{c}\text { 6-unit Gomx-4B } \\
\text { CubeSat }\end{array}$ & $\begin{array}{c}\text { Micro-or } \\
\text { minisatellite }\end{array}$ & $\begin{array}{c}\text { Micro-or } \\
\text { minisatellite }\end{array}$ & $\begin{array}{c}\text { 6-unit PhiSat-1 } \\
\text { CubeSat }\end{array}$ & 12-unit CubeSat \\
\hline $\begin{array}{l}\text { Mission/ } \\
\text { Activity }\end{array}$ & GSTP & $\begin{array}{c}\text { GSTP } \\
\text { (In Orbit } \\
\text { Demonstration) }\end{array}$ & TRP & GSTP & $\begin{array}{c}\text { In-orbit } \\
\text { demonstration }\end{array}$ & GSTP \\
\hline Involvement & $\begin{array}{c}\text { AMOS, } \\
\text { Spacebel, } \\
\text { Centre Spatial } \\
\text { de Liege, }\end{array}$ & $\begin{array}{l}\text { Cosine research } \\
\text { B.V., VITO, } \\
\text { S [\&] T AS, }\end{array}$ & $\begin{array}{c}\text { AMOS, Horiba } \\
\text { Jobin-Yvon }\end{array}$ & $\begin{array}{l}\text { Media Lario, } \\
\text { TSD Space }\end{array}$ & $\begin{array}{c}\text { Cosine research } \\
\text { B.V }\end{array}$ & $\begin{array}{l}\text { VITO, IMEC, } \\
\text { DELTATEC, } \\
\text { AMOS, }\end{array}$ \\
\hline
\end{tabular}




\begin{tabular}{|c|c|c|c|c|c|c|}
\hline & $\begin{array}{l}\text { Deltatec, } \\
\text { Caeleste }\end{array}$ & TU Delft & & & & $\begin{array}{l}\text { Aerospacelab, } \\
\text { Spacebel }\end{array}$ \\
\hline Purpose & $\begin{array}{c}\text { Land } \\
\text { observation }\end{array}$ & $\begin{array}{c}\text { Vegetation, } \\
\text { natural disaster } \\
\text { monitoring }\end{array}$ & $\begin{array}{l}\text { Atmospheric } \\
\text { sensing }\end{array}$ & $\begin{array}{l}\text { Agriculture, } \\
\text { forestry, } \\
\text { hydrology, } \\
\text { resources, urban }\end{array}$ & $\begin{array}{l}\text { Measure soil } \\
\text { moisture, ice } \\
\text { extent, ice } \\
\text { thickness and } \\
\text { detect melting } \\
\text { ponds }\end{array}$ & $\begin{array}{l}\text { Vegetation, } \\
\text { agriculture, } \\
\text { biodiversity }\end{array}$ \\
\hline Status & $\begin{array}{l}\text { Engineering } \\
\text { Model }\end{array}$ & $\begin{array}{l}\text { Launched in } \\
2018\end{array}$ & $\begin{array}{l}\text { 2019: Tested } \\
\text { breadboard }\end{array}$ & $\begin{array}{l}\text { Proto-Flight } \\
\text { Model }\end{array}$ & $\begin{array}{c}\text { Launched in } \\
2020\end{array}$ & $\begin{array}{l}\text { 2022 (Proto- } \\
\text { Flight Model) }\end{array}$ \\
\hline Altitude & $600 \mathrm{~km}$ & $500 \mathrm{~km}$ & $800 \mathrm{~km}$ & $600 \mathrm{~km}$ & $540 \mathrm{~km}$ & $500 \mathrm{~km}$ \\
\hline Swath & $70 \mathrm{~km}$ & $220 \mathrm{~km}$ & $1 \mathrm{~km}$ & $11 \mathrm{~km}$ & $310 \mathrm{~km}$ & $80 \mathrm{~km}$ \\
\hline Design & $\begin{array}{c}\text { Modified Offner } \\
+ \text { free-form } \\
\text { grating }\end{array}$ & $\begin{array}{c}\text { Three-mirror } \\
\text { anastigmat }+ \\
\text { linear variable } \\
\text { filter }\end{array}$ & $\begin{array}{c}\text { Offner-based } \\
\text { (free-form) }+ \\
\text { free-form } \\
\text { grating }\end{array}$ & $\begin{array}{c}\text { Three-mirror } \\
\text { anastigmat }+ \\
\text { linear variable } \\
\text { filter }\end{array}$ & $\begin{array}{c}\text { Three-mirror } \\
\text { anastigmat }+ \\
\text { beam splitter to } \\
\text { divide channels }\end{array}$ & $\begin{array}{c}\text { Three-mirror } \\
\text { anastigmat }+ \\
\text { linear variable } \\
\text { filter }\end{array}$ \\
\hline $\begin{array}{l}\text { Spectral } \\
\text { range }\end{array}$ & $400-2450 \mathrm{~nm}$ & $400-1000 \mathrm{~nm}$ & $600-800 \mathrm{~nm}$ & $430-880 \mathrm{~nm}$ & $\begin{array}{l}400-1000 \mathrm{~nm} \\
\& 8.0-14 \mu \mathrm{m}\end{array}$ & $475-900 \mathrm{~nm}$ \\
\hline $\begin{array}{c}\text { Spectral } \\
\text { bands }\end{array}$ & Up to 120 & 45 & TBC & Up to 150 & 48 & $\begin{array}{c}50(470-620 \mathrm{~nm}) \\
104(600-900 \\
\mathrm{nm})\end{array}$ \\
\hline $\begin{array}{c}\text { Spectral } \\
\text { resolution }\end{array}$ & $2.5 \mathrm{~nm}$ & $12 \mathrm{~nm}$ & $0.5 \mathrm{~nm}$ & $\sim 3 \mathrm{~nm}$ & $12 \mathrm{~nm}$ & $5 \mathrm{~nm}$ (typical) \\
\hline $\begin{array}{c}\text { Spatial } \\
\text { resolution }\end{array}$ & $35 \mathrm{~m}$ & $70 \mathrm{~m}$ & $1 \mathrm{~km}$ & $5.5-11 \mathrm{~m}$ & $75 \mathrm{~m}$ and $490 \mathrm{~m}$ & $20 \mathrm{~m}$ \\
\hline $\begin{array}{l}\text { Temporal } \\
\text { resolution }\end{array}$ & TBC & $\begin{array}{c}45 \text { days (global), } \\
\text { daily revisit }\end{array}$ & TBC & $\sim 1$ week & Order of hours & $\sim 1$ week \\
\hline $\begin{array}{c}\text { Constellatio } \\
n \text { ideas }\end{array}$ & $\begin{array}{l}\text { Small satellite } \\
\text { constellations }\end{array}$ & $\begin{array}{c}\text { With e.g. } \\
\text { constellation of } \\
16,2 / \text { hour } \\
\text { revisit or } 2 / \text { day } \\
\text { global coverage }\end{array}$ & $\begin{array}{l}\text { Small satellite } \\
\text { constellations }\end{array}$ & $\begin{array}{l}\text { Constellation for } \\
\text { Sentinel-2 } \\
\text { equivalent bands } \\
\text { in high } \\
\text { resolution }\end{array}$ & $\begin{array}{c}\text { Small satellite } \\
\text { constellations } \\
\text { for Earth } \\
\text { Observation }\end{array}$ & $\begin{array}{c}\text { Constellation for } \\
\text { Sentinel-2 data } \\
\text { complementatio } \\
\text { n with a 2-3 } \\
\text { days revisit }\end{array}$ \\
\hline $\begin{array}{l}\text { Instrument } \\
\text { weight }\end{array}$ & $35 \mathrm{~kg}$ & $1.3 \mathrm{~kg}$ & TBC & $20 \mathrm{~kg}$ & $1.7 \mathrm{Kg}$ & $4.5 \mathrm{~kg}$ \\
\hline $\begin{array}{l}\text { Instrument } \\
\text { dimensions }\end{array}$ & $\begin{array}{c}500 \times 500 \times 350 \\
\mathrm{~mm}^{3}\end{array}$ & $\begin{array}{l}\text { 1-unit CubeSat } \\
\text { compatible }\end{array}$ & $\begin{array}{c}350 \times 250 \mathrm{~mm}^{2} \\
\text { envelope optical } \\
\text { instrument }\end{array}$ & $\begin{array}{c}615 \times 600 \times 348 \\
\mathrm{~mm}^{3}\end{array}$ & $\begin{array}{c}19 \times 13 \times 12 \\
\mathrm{~cm}^{3}\end{array}$ & $\begin{array}{c}210 \times 223 \times 212 \\
\mathrm{~mm}^{3}\end{array}$ \\
\hline Power & $8.27 \mathrm{~W}$ & $11 \mathrm{~W}$ & TBC & $17 \mathrm{~W}$ & $12 \mathrm{~W}$ & $\sim 5 \mathrm{~W}$ \\
\hline
\end{tabular}

\section{KEY TECHNOLOGIES}

During the course of ESA Basic Research Technology Programme and General Support Technology Programme activities, a good number of new key technologies for hyperspectral instruments were identified. Some of them are discussed in more detail in the following sections. 


\subsection{Free-form mirrors}

A free-form surface is defined as a surface without rotational symmetry. This provides more degree of freedom to the optical designed to compensate for aberrations, furthermore it gives more flexibility for the positioning of optical components and of the image plane. Additional benefits are the avoidance of designs with obscuration, an enhanced image quality at steady volume and a larger field of view. Usually, a high signal-to-noise ratio can be maintained at low distortion values and designs can be made more compact or even reduced in number of components. The reduction of instrument components has again a positive influence on the ease of alignment, volume and cost.

Such geometries could be also manufactured by the implementation of new additive manufacturing techniques using craved internal volumes and materials such AlSi40 or Scalmalloy, which would help to reduce the final components mass.

\subsection{Free-form gratings}

Gratings on free-form surfaces have been developed to provide one more parameter in the optimization of the optical design to reduce keystone and smile of spectrometer. Although this solution may be the source of additional complexity to a delicate optical element such as the grating, it proved to be a key component to minimize the number of optical elements.

\subsection{Hyperspectral Linear Variable Filter}

Instead of using a grating or a prism as dispersive spectrometer element, a hyperspectral system can also be designed by placing a linear variable filter in front of a CMOS detector. These filters are thin film Fabry-Perot interference filters with varying thickness and a narrow wavelength band that gradually changes across the filter. Usually, these filters are deposited on a glass substrate and then mounted on the detector, with potential alignment errors. Recent technology developments allowed to deposit the filters directly on the detector with nanometer accuracy, therefore resolving alignment problems. Furthermore, the filter application on a back side illuminated design allows for a higher quantum efficiency, and therefore a better signal-to-noise ratio. These technologies were developed within the frame of ESA Basic Research Technology Programme and General Support Technology Programme activities.

\subsection{On-board data processing and super resolution deep learning}

High resolution hyperspectral instruments generate a very large amount of data, in the range of one TB per orbit, exceeding by far satellite's downlink capabilities, especially in the case of smallsat platforms. Instead of finding compromises to achieve data compression to achieve a manageable data volume for a small satellite, the path followed with the HyperScout development has been to pursue an on-board data processing to extract Level 2 data on-board in real time. An algorithm to calculate the Normalized Difference Vegetation Index in real time has been developed and tested. This work demonstrated that this mode of operation is within reach of a miniaturized payload using commercial off-the-shelf components currently available. Further device updates lead to the creation of HyperScout 2, which was designed including an Artificial Intelligence (AI) Eyes of Things processing unit ${ }^{27}$. Cosine B.V, claims that this new development represented the first hyperspectral orbiting device that using $\mathrm{AI}^{22}$.

In addition to the reduction of data volume, the possibility of extracting information in real time on board will offer significant advantages for any phenomena where a prompt alert can trigger quick reaction, such as flooding, landslides, volcanic eruptions and so on.

\subsection{Coatings}

Another key technology in continuous development are structural and optical coatings. Enhancement in new materials and coating techniques will provide more competitive devices, by increasing their current optical efficiency and wavelength band capabilities, while structural black-painting coating would help to reduce stray light related issues. Examples of it are the recent years improved efficiency in UV coatings, extending their working ranges down to 50-250 nm, while still achieving efficiencies up to $70-80 \%$ by using MgF2 or LiF materials. Or advances in black coatings as provided by Acktar or Vantablack, which could serve to reduce stray light effects while also using lighter baffling components. 


\section{OTHER RELEVANT HYPERSPECTRAL DEVICE OUTSIDE ESA}

Although in this updated review authors showed the hyperspectral devices supported by ESA, one should not forget other Space Agencies where important steps are also being made. Some of the most relevant launched and in development devices are:

- Hyperion. From NASA and launched in $2000^{1}$.

- $\quad$ TianGong-1. From China ${ }^{28}$.

- DESIS. From DLR and mounted on the ISS in $2018^{29}$.

- EnMAP. From DLR and planed for 2021-2022 ${ }^{30}$.

- SHALOM. From ASI-ISA planed for $2022^{1}$.

Amongst many more that slowly start populating our skies.

\section{CONCLUSION}

This article presents an overview of the hyperspectral instruments related to ESA missions. Hyperspectral technologies and instruments, developed under ESA R\&D contracts, were summarized and described in detail. Hyperspectral instruments and supporting technologies are currently experiencing a very dynamic phase. Applied technologies, processes, designs and application possibilities are far from being exhausted. Clearly, the trend of technology developments allows compact and cost-effective instrument designs with a short revisit time and quick information access, while keeping the data processing flexible for the use in different applications. At the same time, significant efforts are put into the implementation of the technology steps to match the challenging requirements of the Copernicus Space Component Expansion programme.

\section{ACKNOWLEDGEMENTS}

Authors want to thank all industry partners and other members of the ESA/ESTEC TEC-MMO (Mechatronics \& Optics) section for their support and dedication.

\section{REFERENCES}

[1] Transon, J., D'andrimont, R., Maugnard, A. and Defourny, P., "Survey of Hyperspectral Earth Observation Applications from Space in the Sentinel-2 Context," Remote Sensing 10(2), 157 (2018).

[2] ESA, "Sentinel Online: Home > Technical Guides > Sentinel-3 OLCI > OLCI Instrument > Description," 20002019. [Online], https://sentinel.esa.int/web/sentinel/technical-guides/sentinel-3-olci/olci-instrument/description (Accessed 14 August 2019).

[3] W. M. Organization, "Instrument: CHRIS," Observing Systems Capability Analysis and Review Tool, 28 March 2017, [Online], https://www.wmo-sat.info/oscar/instruments/view/82 (Accessed 14 August 2019).

[4] ESA, "Home > Missions > ESA EO Missions > Envisat > Instruments > SCIAMACHY > Design," ESA Earth Online, 2000-2019, [Online], https://earth.esa.int/web/guest/missions/esa-operational-eomissions/envisat/instruments/sciamachy/design (Accessed 14 August 2019).

[5] Aura Mission (EOS/Chem-1) "OMI instrument," [Online], https://earth.esa.int/web/eoportal/satellitemissions/a/aura (Accessed 22 December 2020).

[6] Van Mola, B. and Ruddicka, K., "The Compact High Resolution Imaging Spectrometer (CHRIS): the future of hyperspectral satellite sensors," Imagery of Oostende coastal and inland waters, Bruges, (2004). 
[7] World Meteorological Organization, "Instrument: GOME-2," World Meteorological Organization, 19 March 2018, [Online], https://www.wmo-sat.info/oscar/instruments/view/167 (Accessed 14 August 2019).

[8] World Meteorological Organization, "OSCAR > Instrument: TROPOMI," 2018, [Online], https://www.wmosat.info/oscar/instruments/view/586 (Accessed 14 August 2019).

[9] PRIMSA, [Online], https://earth.esa.int/web/eoportal/satellite-missions/p/prisma-hyperspectral (Accessed 22 December 2020).

[10] Bazalgette Courrèges-Lacoste, G., Ahlers, B., Guldimann, B., Short, A., Veihelmann, B. and Stark, H., "The Sentinel-4/UVN instrument on-board MTG-S," [Online]. https://www.eumetsat.int/cs/idcplg?IdcService=GET FILE\&dDocName=pdf_conf_p59 s1_01 bazalget_p\&all owInterrupt=1\&noSaveAs=1\&RevisionSelectionMethod=LatestReleased (Accessed 14 August 2019).

[11] Coppo, P., Taiti, A., Pettinato, L., Francois, M., Taccola M. and Drusch, M., "Fluorescence Imaging Spectrometer (FLORIS) for ESA FLEX MIsison," Remote Sensing 9(7), 649 (2017).

[12] ESA, "eoPostral Directory: Home > Directory > Satellite Missions > C > Copernicus: Sentinel-5," 2000-2019. [Online]. https://earth.esa.int/web/eoportal/satellite-missions/c-missions/copernicus-sentinel-5 (Accessed 14 August 2019).

[13] World Meteorological Organization, "OSCAR > Instrument: Sentinel-5," 14 August 2019, [Online], https://sentinel.esa.int/web/sentinel/missions/sentinel-5 (Accessed 12 February 2021).

[14] World Meteorological Organization, "OSCAR>Instrument: FLORIS," 31 July 2017, [Online], https://www.wmosat.info/oscar/instruments/view/1168 (Accessed 14 August 2019).

[15] Pinty, B., Janssens-Maenhout, G., Dowell M., and Zunker, H., "Toward an operational capacity to monitor fossil fuel CO2 emissions," 2018, [Online], https:/www.che-project.eu/sites/default/files/2018-02/1stGAPinty.pdf (Accessed 14 August 2019).

[16] Bach, H., Rast M., and Nieke, J., "CHIME-The Copernicus Hyperspectral Imaging Mission," 2018 [Online], https://www.dcopernicus.de/fileadmin/Content/pdf/Forum 2018/2018 1108 CHIME Copernicus Bonn Vista.pdf (Accessed 14 August 2019).

[17] Thales, "CHIME," [Online], https:/www.thalesgroup.com/en/worldwide/space/press-release/thales-aleniaspace-build-copernicus-chime-satellites (Accessed 12 February 2021).

[18] ESA, "eoPortal Directory: Home > Directory > Satellite Missions > G > GomX-4," 2001-2019, [Online], https://directory.eoportal.org/web/eoportal/satellite-missions/g/gomx-4 (Accessed 14 August 2019).

[19] Zuccaro Marchi, A., Maresi L., and Taccola, M., "Technologies and Designs for Small Optical Missions," in ICSO, Chania (2018).

[20] Cosine, "HyperScout-2," [Online], https://www.cosine.nl/cases/hyperscout-2/ (Accessed 30 December 2020).

[21] ESA, "PhiSat-1 HyperScout-2," [Online], https://directory.eoportal.org/web/eoportal/satellite-missions/p/phisat$1 \#$ foot $2 \% 29$ (Accessed 30 December 2020).

[22] Cosine, "HyperScout-2," [Online], Available: https://www.cosine.nl/hyperscout-2-in-space-first-hyperspectralthermal-camera-with-artificial-intelligence/ (Accessed 23 December 2020).

[23] Media Lario S.r.l., "EARTH OBSERVATION IMAGERS: STREEGO," 2019, [Online], https://www.medialario.com/news/downloads/streego brochure mar 2019.pdf (Accessed 14 August 2019).

[24] Media Lario S.r.1., "HyperSTREEGO: Reactive Payload. 4s-sympossium." [Online], https://www.medialario.com/news/hyperstreego 4s paper 160606 per website.pdf (Accessed 23 December 2020).

[25] De Clercq, C., Moreau, V., Jamoye, J.-F., Zuccaro Marchi, A., and Gloesner, P., "ELOIS: an innovative spectrometer design using a free-form grating," in SPIE Optical Systems Design, Jena, 2015.

[26] Blommaert, J., Delaure, B., Livens, S. and Nuyts, D., "CSIMBA: TOWARDS A SMART-SPECTRAL CUBESAT CONSTELLATION," in IGARSS, Yokohama, 2019.

[27] ESA, "PhiSat-1 Nanosatellite Mission. HyperScout-2," [Online], https://directory.eoportal.org/web/eoportal/satellite-missions/p/phisat-1, (Accessed 23 December 2020).

[28] Li, X., Wu, T., Liu, K., Li, Y. and Zhang, L. "Evaluation of the Chinese Fine Spatial Resolution Hyperspectral Satellite TianGong-1 in Urban Land-Cover Classification," Remote Sens. 8, 438 (2016).

[29] Krutz, D., Müller, R., Knodt, U., Günther, B., Walter, I., Sebastian, I., Säuberlich, T., Reulke, R., Carmona, E., Eckardt, A., Venus, H., Fischer, C., Zender, B., Arloth, S., Lieder, M., Neidhardt, M., Grote, U., Schrandt, F., 
Gelmi, S. and Wojtkowiak, A. "The Instrument Design of the DLR Earth Sensing Imaging Spectrometer (DESIS)," Sensors 19, 1622 (2019). Doi: 10.3390/s19071622.

[30] Guanter, L., Kaufmann, H., Segl, K., Foerster, S., Rogass, C., Chabrillat, S., Kuester, T., Hollstein, A., Rossner, G., Chlebek, C., Straif, C., Fischer, S., Schrader, S., Storch, T., Heiden, U., Mueller, A., Bachmann, M., Mühle, H., Müller, R., Habermeyer, M., Ohndorf, A., Hill, J., Buddenbaum, H., Hostert, P., Van der Linden, S., Leitão, P.J., Rabe, A., Doerffer, R., Krasemann, H., Xi, H., Mauser, W., Hank, T., Locherer, M., Rast, M., Staenz, K. and Sang, B. “The EnMAP Spaceborne Imaging Spectroscopy Mission for Earth Observation,” Remote Sens 7, 88308857 (2015). Doi: 10.3390/rs70708830. 